\title{
Occurrence of target spot of tomato caused by Corynespora cassiicola in Sri Lanka
}

W.A.P.G. Weeraratne, W.M.S.D.K. Wijerathne and D.M.K.K. Dissanayake

\section{TARGET SPOT OF TOMATO}

\section{Corynespora cassiicola}

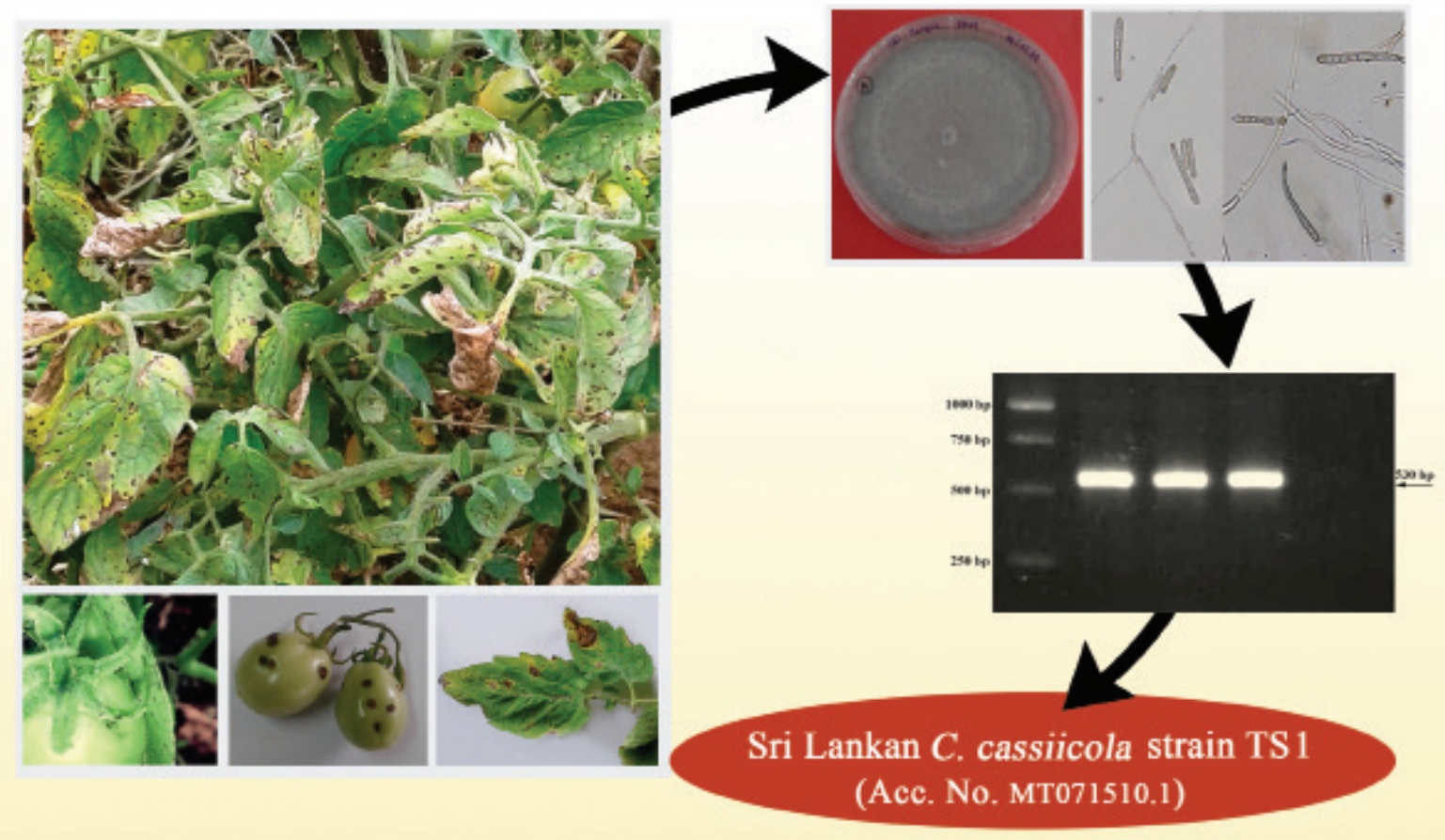

\section{Highlights}

- Cottony, grayish fungal colony on PDA and cylindrical, straight, multi-septate conidia

- Corynespora cassiicola was identified based on morphological, molecular and pathological data

- Sri Lankan C. cassiicola strainTS-1 (GenBank Accession No. MT071510.1)

- 97 \% sequence identity with C. cassiicola in GenBank Accession No. MH780759 


\title{
SHORT COMMUNICATION
}

\section{Occurrence of target spot of tomato caused by Corynespora cassiicola in Sri Lanka}

\author{
W.A.P.G. Weeraratne*, W.M.S.D.K. Wijerathne and D.M.K.K. Dissanayake \\ Horticultural Crop Research and Development Institute, Gannoruwa, Peradeniya, Sri Lanka
}

Received: 28/02/2020 ; Accepted: 06/10/2020

\begin{abstract}
In February 2019, a new destructive leaf and stem spot disease was reported from commercial tomato fields in Kimbissa, Central Province, Sri Lanka. This disease resulted in significant loss of foliage where the disease severity ranged from $50-70 \%$ in the infected tomato fields. The objectives of the study were to isolate and characterize the pathogen causing the disease and confirm its pathogenicity. A fungal pathogen with cottony, grayish mycelium and cylindrical, straight, multi-septate conidia was isolated from the leaf and stem lesions on Potato Dextrose Agar PDA. Based on morphological, molecular and pathological data, the fungus was identified as Corynespora cassiicola. Reinoculation of leaves and stems of healthy tomato plants under green house conditions produced symptoms similar to those observed in the field. Sequence was deposited in GenBank for Sri Lankan C. cassiicola strain TS-1 (Accession No.MT071510.1). A
\end{abstract}

BLAST search revealed $97 \%$ sequence identity to Corynespora cassiicola in GenBank Accession No. MH780759.1 (Soybean, Brazil).

Keywords: Molecular identification, Target spot, Tomato.

\section{INTRODUCTION}

Tomato (Solanum lycopersicum L.), belonging to the family Solanaceae, is one of the most popular vegetable crops grown in Sri Lanka. Many constraints affect productivity and quality of tomato among which diseases caused by fungi, bacteria, viruses and phytoplasma play a major role. In February 2019, a destructive leaf and stem spot disease was reported from farmer fields of tomato in Kimbissa, Central Province of Sri Lanka, which has

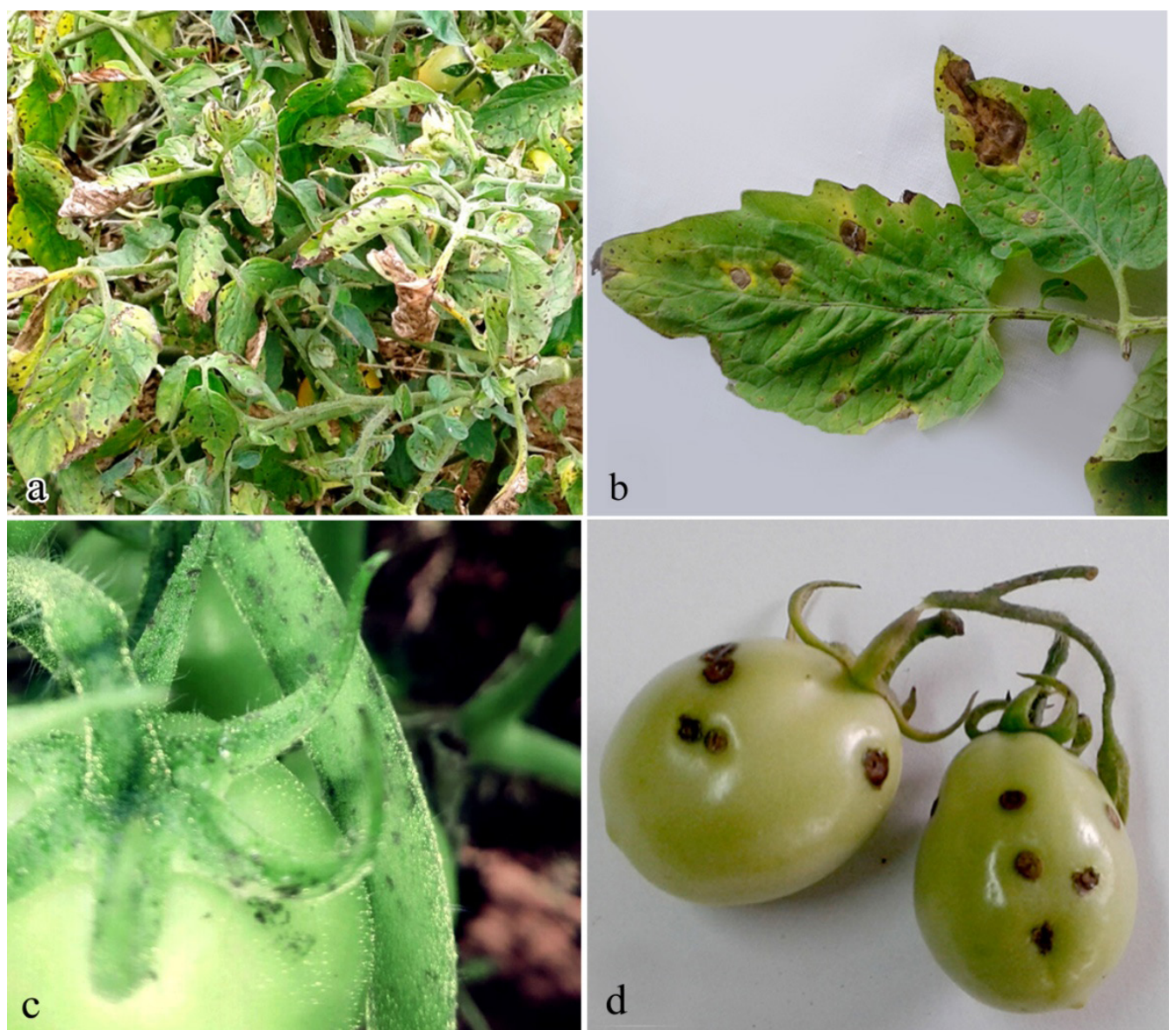

Figure 1: (a) Severely infected tomato plants showing target spot symptoms, (b) in leaves, (c) stem, and (d) fruits at farmers' field in Kimbissa.

*Corresponding Author's Email: gethweeraratne@gmail.com

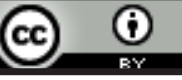

This article is published under the Creative Commons Attribution License (https://creativecommons.org/licenses/by/4.0/), which permits unrestricted use, distribution, and reproduction in any medium, provided the original work is properly cited. 
resulted a significant loss of foliage. The disease severity ranged $50-70 \%$ in the affected tomato fields. The infected tomato plants exhibited brown spotting on leaves and stems, spreading on to all leaflets (Figure 1a).

Affected plants exhibited symptoms, initially as small brown lesions with a yellow halo on leaves and later spread to the petiole, stems (Figure $1 \mathrm{~b} \& \mathrm{c}$ ) and fruits. These lesions become larger, showing "target spot" appearance and coalesced lesions on the stems were longer and thinner whereas brown to dark brown sunken lesions occur on fruits (Figure 1d), resulting reduced fruit quality and yield. These symptoms were similar to those of target spot disease of tomato caused by $C$. cassiicola as described by Schlub et al. (2007).

Early stage of brown spot symptoms on leaves were quite similar to that of early blight of tomato caused by Alternaria solani (Adam et al., 2018). Hence, the confirmation of the pathogen of this destructive disease is important for formulating management strategies against it. The objectives of the present study were to identify the pathogen of target spot disease in tomato in Sri Lanka, using morphological and molecular techniques and to confirm its pathogenicity.

\section{MATERIALS AND METHODS}

\section{Isolation and characterization of the pathogen}

Samples of infected leaf, stem and petiole were collected from exotic tomato variety 'Platinum' from two locations at Kimbissa area in February 2019. Isolation and molecular identification studies were conducted at the Horticultural Crop Research and Development Institute (HORDI), Gannoruwa, Sri Lanka. Isolations were made from affected leaves (TS1), stems (TS2) and petioles (TS3) on Potato Dextrose Agar (PDA) medium.

Small pieces of tissues, excised from symptomatic areas, were surface sterilized in $70 \%$ ethanol for $2-3 \mathrm{~min}$ (Jayasuriya and Thennakoon, 2007) and transferred on to PDA plates supplemented with streptomycin $0.1 \% \mathrm{~W} / \mathrm{V}$. The plates were incubated at room temperature, $26 \pm 2$ ${ }^{\circ} \mathrm{C}$. After 1-2 days of incubation, the fungal mycelium grown out of the diseased tissues were sub-cultured and the plates were incubated for $7-14$ days at $26 \pm 2{ }^{\circ} \mathrm{C}$. Single spore isolates were raised from all cultures which were maintained as axenic cultures on PDA at $4{ }^{\circ} \mathrm{C}$ for further use. Morphological characteristics of colonies, grown on PDA, were described and the morphology of fungal structures were observed under light microscope and recorded.

\section{Molecular identification}

Total genomic DNA was extracted from pure cultures of three pathogenic isolates (TS1, TS2 and TS3) using Cetrimide Tetradecyl Trimethyl Ammonium Bromide (CTAB) extraction procedure (ICGEB, 2003). Polymerase Chain Reaction (PCR) amplification with universal primers, ITS1 (5'-TCCGTAGGTGAACCTGCGG-3') which anneals at the end of $18 \mathrm{~S}$ rDNA and ITS4 (5'-TCCTCCGCTTATTGATATGC-3') which anneals at the beginning of 28s rDNA (White et al., 1990). PCR amplifications were performed in a total volume of $10 \mu \mathrm{l}$ by mixing $5 \mu \mathrm{l}$ of Taq PCR master mixture (Promega- 25 units Taq DNA polymerase, $200 \mu \mathrm{M}$ of each dNTP and 1X PCR buffer and $\left.1.5 \mathrm{mM} \mathrm{MgCl}_{2}\right), 0.8 \mu \mathrm{l}$ of each primer (10 $\mathrm{mM}), 0.5 \mu \mathrm{l}$ of diluted (1:10) DNA template and $2.9 \mu \mathrm{l}$ of sterile distilled water. PCR program included an initial denaturation of $5 \mathrm{~min}$ at $94{ }^{\circ} \mathrm{C}$, followed by 35 cycles of 1 min at $94{ }^{\circ} \mathrm{C}, 1 \mathrm{~min}$ at $55^{\circ} \mathrm{C}$ and $1 \mathrm{~min}$ at $72{ }^{\circ} \mathrm{C}$ with a final extension at $72{ }^{\circ} \mathrm{C}$ for $10 \mathrm{~min}$. using a thermo cycler (Labnet Gradient, USA). PCR products were visualized in $1.4 \%$ agarose gel for $01 \mathrm{~h}$ at $80 \mathrm{~V}$ and using a gel documentation system (ENDURO ${ }^{\mathrm{TM}}$ GDS). Promega- G571A 1 kb ladder was used as a marker.

PCR products were sequenced at the Department of Molecular Biology and Biotechnology, Faculty of Science, University of Peradeniya, Sri Lanka and were subjected to DNA homology search with BLAST (http:www.ncbi.nlm.gov/ BLAST/).

\section{Confirmation of pathogenicity}

Pathogenicity of three fungal isolates was tested on 3-week old, healthy tomato (var. Thilina) plants, transplanted in plastic pots ( $8 \mathrm{~cm}$ diameter), containing sterilized soil mixture under greenhouse conditions at HORDI. A set of three tomato plants per isolate was inoculated by spraying a conidial suspension $\left(1 \times 10^{5} \mathrm{ml}^{-1}\right)$ of each fungal isolate and another set of plants was sprayed with sterile distilled water to serve as controls. All inoculated plants were subsequently kept covered with polyethylene bags, moistened with tap water, for $48 \mathrm{~h}$ to provide high humid conditions. The pathogen was re-isolated from symptomatic tissues as described previously to confirm the pathogenicity.

\section{RESULTS AND DISCUSSION}

\section{Morphological characteristics of the isolated pathogen}

The colonies of three fungal isolates on PDA were morphologically similar. They were cottony and initially white colour and later turned dark gray and the reverse was light to dark brown (Figure 2a; b) as the cultures aged. The conidia were hyaline to brown, cylindrical, straight, some slightly curved and 3 -13 septate often consisting of a protruding peg (hilum) at their base (Figure 2c). Conidial lengths and widths ranged from 40.16 to $279.90 \mu \mathrm{m}$ and 6.87 to $17.3 \mu \mathrm{m}$, respectively. The conidia were taxonomically similar to original description of C. cassiicola (Caetano et al., 2018).

\section{Molecular identification}

Amplification of DNA extracts from the 3 isolates of Corynespora sp. with universal primer pair, ITS1 and ITS4, generated approximately 530 base pair rDNA fragment and no band was produced with water controls in any of the reactions (Figure 3). The BLASTn search revealed 97\% sequence identity to Corynespora cassiicola isolate Cc318-1 in GenBank Accession No. MH780759.1 (Soybean, Brazil). The sequence of C. cassiicola strain TS1 (Tomato, Sri Lanka) was deposited in GenBank Accession No.MT071510.1. 

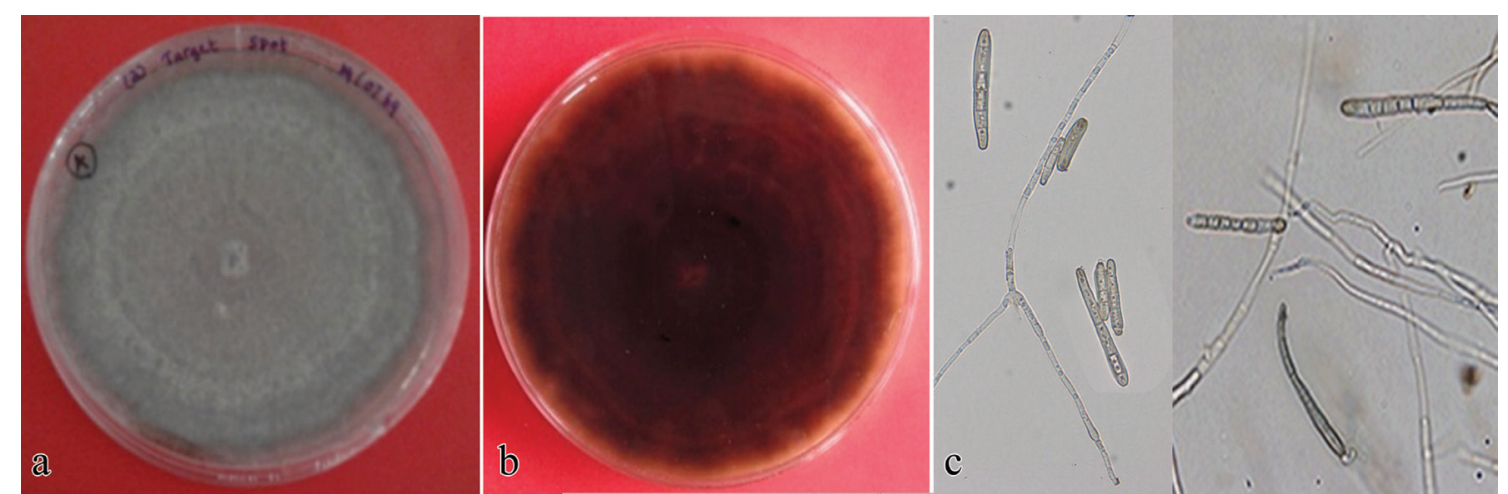

Figure 2: a) Upper and, b) lower surface view of C. cassiicola isolate TS1 grown on PDA after 10 days, and c) conidia (x 400).

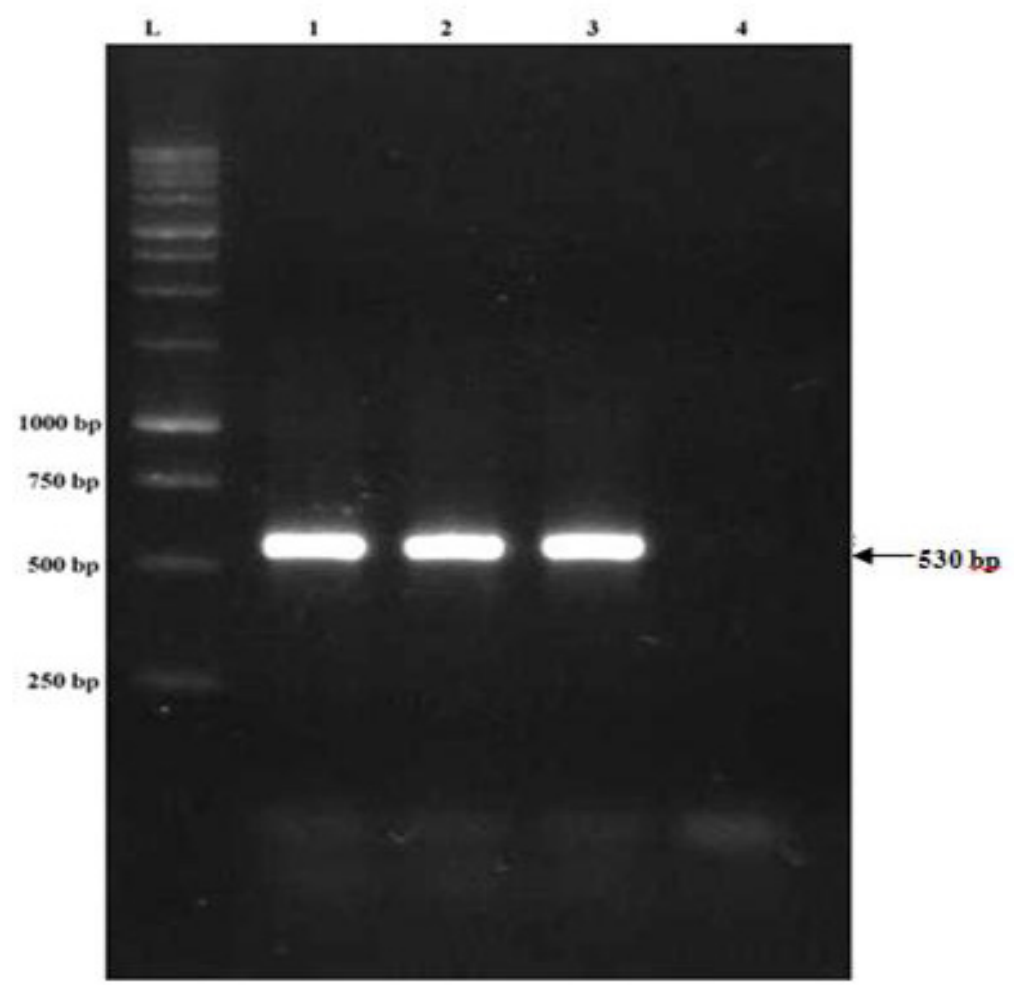

Figure 3: Electrophoresis in agarose gel of PCR amplification products with ITS1 and ITS4 primers for Corynespora cassiicola. Lanes L: DNA ladder, 1: Isolate TSI, 2: Isolate TS2, 3: Isolate TS3, 4: negative control
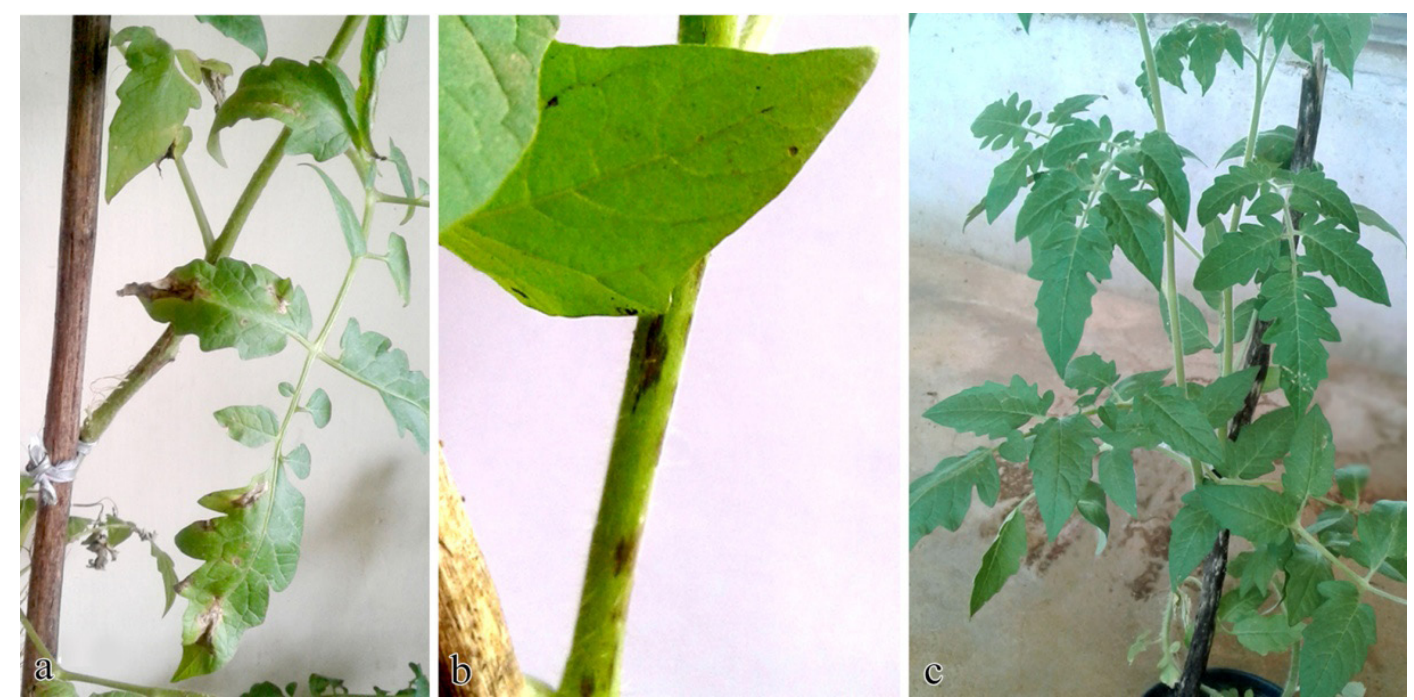

Figure 4: Target spot symptoms development on a) leaves and b) stem inoculated with C. cassiicola isolate TS1 and c) control plant 


\section{Confirmation of Pathogenicity}

Five days after inoculation, all three $C$. cassiicola isolates initiated spot symptoms on leaves and stems of tomato plants (Figure $4 \mathrm{a} ; \mathrm{b}$ ). The symptoms were identical to those observed in the field. The control plants remained healthy (Figure 4c). The pathogen was re-isolated from inoculated plants and the colonies recovered were similar to those isolates originally obtained from diseased plants.

The fungus has been reported to infect 380 genera and 530 species of plants including monocots, dicots and ferns (Smith et al., 2006). Corynespora cassiicola is a serious pathogen on winter tomato production areas of Florida, USA and causes heavy losses up to $11,800 \mathrm{~kg} / \mathrm{ha}$ when the disease is not managed (Pernezny et al., 2002). Target spot has been identified as one of the major threats to tomato production in India and disease severity ranged between $35 \%$ and $58 \%$ in different locations of West Bengal which ultimately causes tremendous loss of tomato foliage (Adam et al., 2018).

In Sri Lanka, the fungus has been reported in rubber, cowpea, eggplant, winged bean, tomato, cocoa, papaya, sweet potato and manioc (Silva et al., 2000). This is the first report of molecular identification of the pathogen causing target spot disease in tomato grown in Sri Lanka.

\section{CONCLUSIONS}

The pathogen causing the leaf and stem spot disease of tomato was identified as $C$. cassiicola. The BLASTn search revealed $97 \%$ sequence identity to $C$. cassiicola isolate Cc318-1 in GenBank Accession Nos. MH780759.1. Sequence was deposited in GenBank for Sri Lankan $C$. cassiicola strain TS-1 (Accession No. MT071510.1).

\section{ACKNOWLEDGEMENT}

The authors wish to express their appreciation to the Department of Agriculture, Sri Lanka for funding this study.

\section{DECLARATION OF CONFLICT OF INTEREST}

The authors declare no conflict of interests.

\section{REFERENCES}

Adam, K., Subrata, D., Kanishendranath, S., Siddhartha, D., Gouranga, D. and Suraj, G. (2018). Target leaf spot of tomato incited by Corynespora cassiicola, an emerging disease in tomato production under Gangetic alluvial region of West Bengal, India. Archives of Phytopathology and Plant Protection 51(19-20): 10391048 DOI:10.1080/03235408.2018. 1545281.

Caetano, A.O., Diniz, R.L.C., Lemes, N.M., Rietjens, A.R., Lima, M.L.P. (2018). Symptomatology, hosts, and pathogenicity of Corynespora cassiicola. Journal of Neotropical Agriculture 5(2): 48-53 DOI: 10.32404/ rean.v5i2.1410

ICGEB (2003). Workshop Handbook on genomics and crop improvement. International Centre for Genetic Engineering and Biotechnology 47-51.

Jayasuriya, K.E. and Thennakoon, B.I. (2007). First report of Corynespora cassiicola on Codiaeum variegatum (croton) in Sri Lanka. Ceylon Journal of Science (Bio. Sci.) 36(2): 138-141.

Pernezny, K., Stoffella, P., Collins, J., Carroll, A., and Beaney, A. (2002). Control of target spot of tomato with fungicides, systemic acquired resistance activators, and a biocontrol agent. Plant Protection Science 38(3): 8188.

Schlub, R. L., Smith, L. J., Datnoff, L. E., and Pernezny, K. (2007). An overview of target spot of tomato caused by Corynespora cassiicola. II International Symposium on Tomato Diseases. Acta Horticulturae 808: 25-28.

Silva, W.P.K., Wijesundera, R.L.C., Karunanayake, E.H., Jayasinghe, C.K. and Priyanka, U.M.S. (2000). New Hosts of Corynespora cassiicola in Sri Lanka. Plant Disease 84(2): 202.

Smith, L.J., Datnoff, L.E., Pernezny, K.L., Roberts, P.D., Rollins, J.A., Schlub, R.L. and Scott, J.W. (2006). Characterization and host-range of the tomato target spot fungus, Corynespora cassiicola and resistance of tomato cultivars. Florida Tomato Committee, Tomato Research Report for 2004-2005, pp 14-20

White T.J., Bruns T., Lee S. and Taylor J.W. (1990). Amplification and direct sequencing of fungal ribosomal RNA genes for phylogenetics. In Innis, M.A., D.H. Gelfand, J.J. Sninsky \& T.J. White (eds.) PCR Protocol: A Guide to Methods and Applications. New York, Academic Press 315- 322 Pp. 